\title{
SEROEPIDEMIOLOGICAL SURVEY OF EQUINE INFECTIOUS ANEMIA IN RONDONIA STATE, BRAZIL
}

\author{
LEVANTAMENTO SOROEPIDEMIOLÓGICO DE ANEMIA INFECCIOSA EQUINA NO \\ ESTADO DE RONDÔNIA, BRASIL
}

\author{
A. C. C. GUIRAUD ${ }^{1}$, M. A. A. BELO ${ }^{2,3}$, A. C. MORAES ${ }^{3}$, W. G. MANRIQUE ${ }^{2}$, L. M. SOUZA ${ }^{2}$, \\ I. CHARLIE- SILVA ${ }^{3}$, E. P. SOUZA ${ }^{4 *}$
}

\begin{abstract}
SUMMARY
Based on the importance of equine infectious anemia (EIA), this study aimed to analyze the spatial distribution and report the occurrence rates of EIA through a seroepidemiological survey and evaluate the actions taken by the Agrosilvopastoral Defence Agency of the State of Rondônia (IDARON) from January 2014 to December 2015. There was a direct relationship between the human development index (HDI) and the number of horses in the different areas of the Rondonia. 7,729 properties were analyzed, in which 19,805 horses were examined, with a mean seropositivity for EIA of $1.15 \%$ in 2014 and $1.01 \%$ in 2015. Despite the low incidence of seropositive horses for the EIA virus, sanitary control procedures imposed by IDARON with the sacrifice of $95.97 \%$ of sick animals in 2014 and $90 \%$ in 2015 resulted in a decrease of $28.22 \%$ of positive animals between the years 2014 and 2015 . Therefore, to achieve an effective reduction in the prevalence of this disease, all positive animals should be isolated and subsequently sacrificed, as they are disseminators of the disease. Many farmers, however, do not understand the real importance of the proliferation of EIA by the presence of carrier animals in the herds.
\end{abstract}

KEY-WORDS: Epidemiology, Horses, Infectious diseases, Lentivirus, Sanitary control

\section{RESUMO}

Com base na importância da Anemia infecciosa Equina (AIE), a presente investigação teve como objetivo analisar a distribuição espacial e relatar os índices de ocorrência de AIE por meio de levantamento soroepidemiológico e ações realizadas pela Agência de Defesa Agrosilvopastoril do Estado de Rondônia (IDARON) no período de janeiro de 2014 a dezembro de 2015. Observou-se uma relação direta entre o índice de desenvolvimento humano (IDH) e o número de equinos nas diferentes regiões do estado de Rondônia. Foram analisadas 7.729 propriedades, nas quais 19.805 equinos foram examinados, obtendo-se uma soropositividade média de 1,15\% em 2014 e 1,01\% em 2015 para AIE. Apesar da baixa ocorrência de equinos sorologicamente positivos para o vírus da AIE, os procedimentos de controle sanitário impostos pela IDARON com o sacrifício dos animais enfermos 95,97\% em 2014 e 90\% em 2015 resultaram em diminuição de $28,22 \%$ de animais positivos entre os anos de 2014 e 2015. Portanto, para se conseguir boa redução na prevalência dessa enfermidade, todo o animal positivo deve ser sacrificado, por ser disseminador da doença. Embora inúmeros criadores, não entendam a real importância para a disseminação da AIE nos plantéis pela presença de animais portadores.

PALAVRAS-CHAVE: Equinos, Doenças infeciosas, Epidemiologia, Lentivirus, Vigilância sanitária

\footnotetext{
${ }^{1}$ Faculty of Amazônia, 743 street, number 2043, Vilhena-RO, Zip code. 76980-000, Brazil.

${ }^{2}$ Brasil University. Hilário Silva Passos Avenue, N 950, Zip code: 13690-000, Descalvado - SP, Brazil

${ }^{3}$ Departament of Preventive Veterinary Medicine, São Paulo State University (UNESP), Via de Acesso Prof. Paulo Donato Castellane, s/n, zona rural, Zip code. 14884-900, Jaboticabal - SP, Brazil

${ }^{4}$ Corresponding author. State Coordinator of Equidae Health - Agrosilvopastoral Defence Agency of the State of Rondônia (IDARON), Porto Velho-RO, Brazil. E-mail.: gidsa.epidemio@idaron.ro.gov.br
} 


\section{INTRODUCTION}

Equine infectious anemia (EIA) is a cosmopolitan disease that affects equidaes, caused by a virus of the genus Lentivirus from the Retroviridae family (COOK et al. 2013; TANG et al. 2016; RICOTTI et al. 2016). EIA is a persistent infection, with periodic episodes of fever, anemia, hemorrhages and leukopenia as well as transient suppression of immune response. Affected animals may also present clinical signs such as weight loss, depression, disorientation, walking in circles and fever. EIA is a transmissible disease that results in serious losses for breeders, as well as preventing access to the international market (FREITAS et al. 2015; COOK et al. 2013; RICOTTI et al. 2016).

According to Ricotti et al. (2016), important factors in the worldwide dissemination of this virus are associated to the inadvertent movement of unapparent carrier equids and iatrogenic transmission. However, the major transmission mechanism for the disease involves participation of vectors, with many species, including tabanids (Tabanus sp. e Hybomitra sp., Chrysops flavidus), stable flys (Stomoxys sp.), blackflys (Simulinium vittatum), mosquitos (Psorophora columbiae, Aedes vexans e Anopheles sp.) and possibly Culicoides sp. (HEINEMANN et al. 2001; ALMEIDA et al. 2006; COOK et al. 2013).

Transmission of the EIA virus (EIAV) is usually a result of the transfer of blood from an infected horse to a healthy recipient, which may develop clinical signs of the disease around 15 to 60 days after exposure, even before it can be diagnosed as positive (COOK et al. 2013; FREITAS et al. 2015). The agar gel immunodiffusion test (AGID), using the p26 viral antigen, to diagnose EIA is considered the worldwide standard (NARDINI et al. 2016).

It was first described in France in 1843 and its viral etiology was determined in 1904, and the distribution of EIA is worldwide, with prevalence reaching as high as $70 \%$ of adult animals in endemic areas (COOK et al. 2013). In Brazil, EIA was report first in 1968 horse infected (ALMEIDA et al. 2006). Prevalence rates tend to be moderate to high in all regions of Brazil. Serological studies in several Brazilian states, such as Pará, Minas Gerais, Mato Grosso do Sul, Goiás and Rio Grande do Sul, have identified the presence of the EIA virus in the equine population in every region of Brazil (SILVA et al. 2015; HEINEMANN et al. 2001; ALMEIDA et al. 2006; BORGES et al. 2013; FREITAS et al. 2015).

Belonging to the Brazilian amazon region, Rondônia state in North of Brazil is part of the largest tropical wetland area of the world. The state encompasses both the Cerrado (tropical Savanna) and Amazonian biomes, with a tropical-humid climate prevalent. Rainfall ranges from $1,900 \mathrm{~mm}$ in the South to $2,500 \mathrm{~mm}$ in the North. Temperature remains high throughout the year, with an annual average of $26^{\circ} \mathrm{C}$. Besides that, has border with portions of Bolivia (Brazilian Institute of Geography and Statistics) (IBGE). Considering the importance of the agribusiness of horses in Brazil, the present study aimed to analyze spatial distribution and to report the occurrence rates of EIA through a seroepidemiological survey in the state of Rondônia in the Brazilian amazon area.

\section{MATERIAL AND METHODS}

The state of Rondônia is located in the northern region of Brazil, approximately 2,163 km from the capital Brasília. According to the Instituto Brasileiro de Geografia e Estatística (Brazilian Institute of Geography and Statistics) (IBGE) Demographic Census of 2015, the state has 1,768,204 inhabitants, distributed across 52 municipalities. Data from the Agrosilvopastoral Sanitary Defense Agency of the state of Rondônia (IDARON) from the period of January 2014 to December 2015 was used. Equine blood samples were collected by veterinarians from the animal health service of IDARON and submitted to accredited laboratories to perform Agar Gel Immunodiffusion (AGID) Test. For production of the thematic map, the data was geocoded with the help of version 7 of the Epiinfo program. Initially, geocoding was performed by cities with positive animal points coded in relation to municipalities using a digital cartographic database.

\section{RESULTS AND DISCUSSION}

The map represented by Figure 1 indicates the spatial distribution of the number of horses examined, while Figure 2 (A and B) presents the spatial analysis of the number of horses and the human development index (HDI), respectively, in the state of Rondônia in 2015. A direct relationship between the HDI and the number of horses in the state was observed. This finding can be justified by the fact that horse breeding has always played a fundamental role in human and economic development in Brazil, being strongly related to the development of cities, as equines have always been used in heavy work, civil construction and cargo transportation as well as in agricultural activities. Horse breeding is currently a secondary activity. In the northern region of the country, equidae are widely used in farming activities, mainly because this region is characteristically made up of landed estates, requiring the use of numerous horses when dealing with livestock.

According to Silva et al. (2015), the majority of horse breeders in the southern and southeastern regions of Brazil are people with a level of education above the national average, such as doctors, lawyers and businessmen, among other professions, as well as of a high socioeconomic and cultural level. Thus, equine culture is associated with improvements in quality of life.

Spatial analysis of Equine Infectious Anemia (EIA) initially enabled the mapping of the frequency of positive cases (Figure 3), the number of affected properties (Figure 4) and the number of animals examined (Figure 1) in the state of Rondônia during 
2014 and 2015. The results observed in the serological analysis for EIA are shown in Table 1 and illustrated in Figure 3. Horses testing positive for EIA are irregularly distributed in practically all Brazilian states. In the state of Rondônia a decrease in the number of positive animals between 2014 (124) and 2015 (89) was observed on the thematic map (Figure 3).

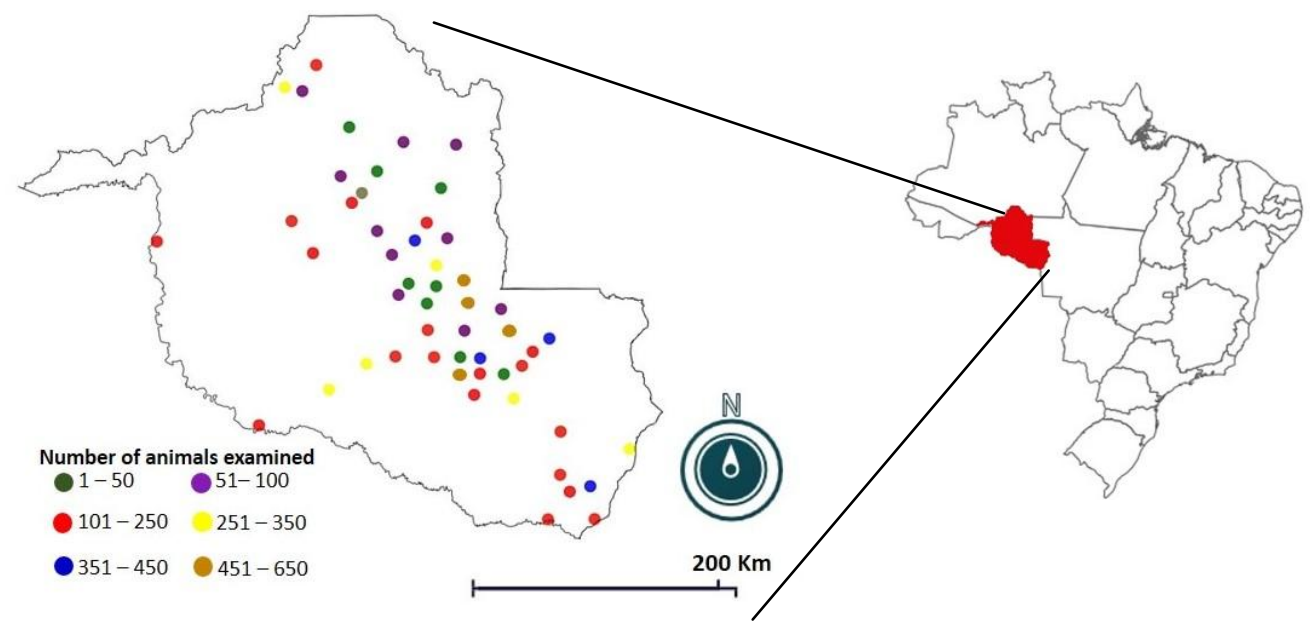

Figure 1 - Spatial distribution of the number of horses examined in the state of Rondônia during 2014 and 2015.
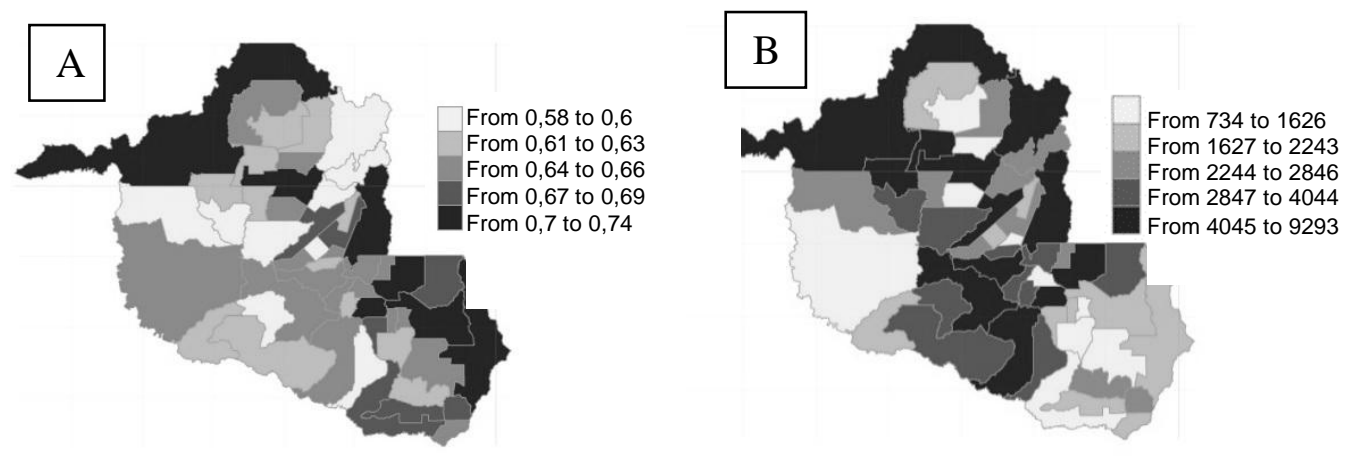

Figure 2 - Data from IBGE regarding spatial distribution of the human development index (A) and the number of horses (B) in the state of Rondônia in 2015.
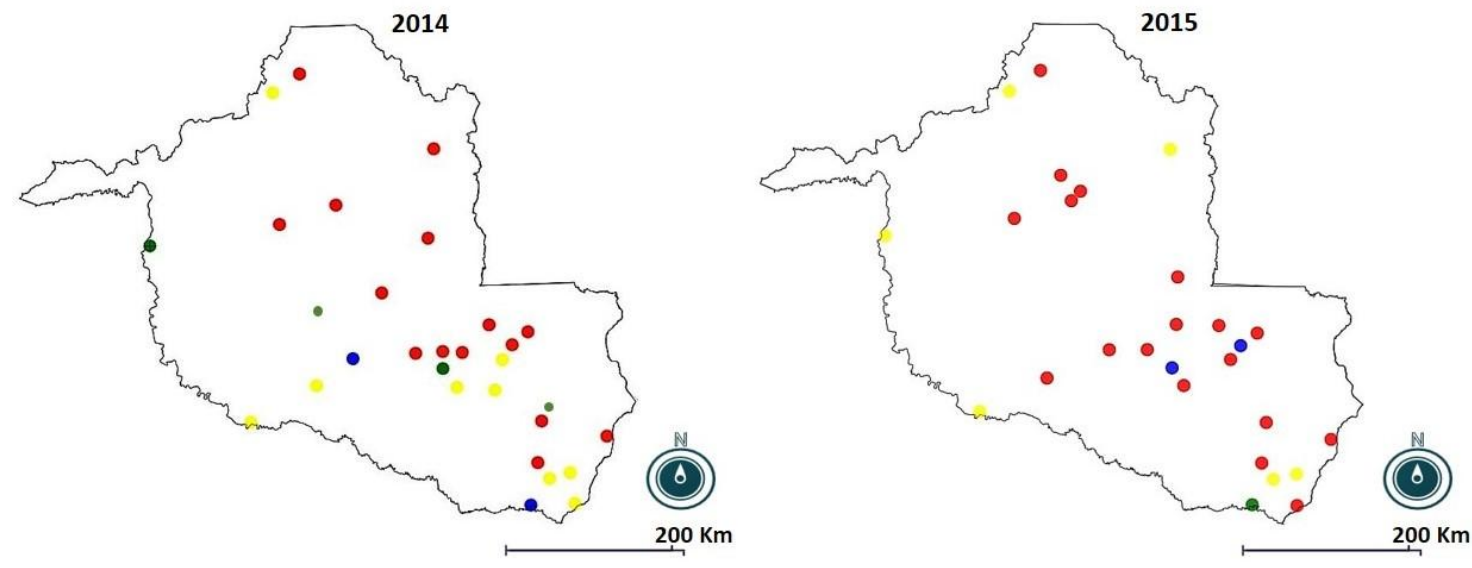

$$
\begin{aligned}
& \text { Number of positive animals } \\
& \begin{array}{l}
1-3 \\
-3-7
\end{array}-8-11 \quad 12-15
\end{aligned}
$$

Figure 3 - Spatial distribution of the number of positive animals in the state of Rondônia during 2014 and 2015. 


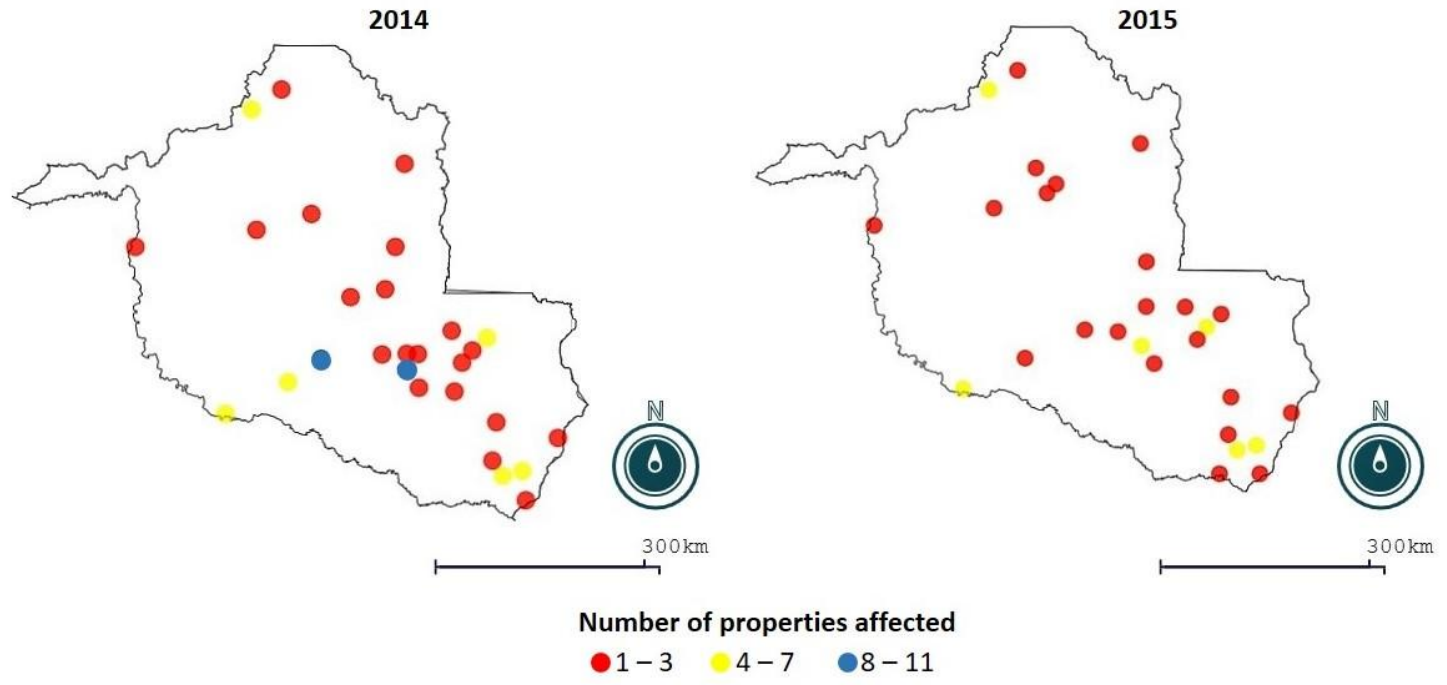

Figure 4 - Spatial distribution of the number of infected properties in the state of Rondônia during 2014 and 2015.

Table 1 - Percentage of horses serologically positive for Equine Infectious Anemia (EIA) in the State of Rondônia, from January 2014 to December 2015.

\begin{tabular}{|c|c|c|c|c|c|c|}
\hline \multicolumn{7}{|c|}{ Equine Infectious Anemia (EIA) } \\
\hline Year & & 2014 & & & 2015 & \\
\hline & $\mathrm{N}^{\mathrm{o}}$ Examined & Positive (\%) & Slaughtered (\%) & $\mathrm{N}^{\mathrm{o}}$ Examined & Positive (\%) & Slaughtered (\%) \\
\hline January & 786 & 1.4 & 100.00 & 645 & 0.31 & 100.00 \\
\hline February & 739 & 0.41 & 100.00 & 588 & 1.19 & 100.00 \\
\hline March & 845 & 0.71 & 100.00 & 728 & 0.69 & 100.00 \\
\hline April & 815 & 1.6 & 100.00 & 991 & 0.91 & 100.00 \\
\hline May & 975 & 1.03 & 90.00 & 890 & 0.9 & 75.00 \\
\hline June & 1361 & 1.1 & 93.33 & 972 & 1.03 & 90.00 \\
\hline July & 1135 & 0.7 & 100.00 & 857 & 2.57 & 90.91 \\
\hline August & 758 & 1.19 & 100.00 & 927 & 1.4 & 92.31 \\
\hline September & 1096 & 1.09 & 100.00 & 785 & 0.76 & 66.67 \\
\hline October & 695 & 2.73 & 100.00 & 637 & 0.94 & 83.33 \\
\hline November & 764 & 0.65 & 80.00 & 425 & 0.47 & 100.00 \\
\hline December & 785 & 1.66 & 84.62 & 606 & 0.17 & 100.00 \\
\hline TOTAL & 10,754 & 1.15 & 95.97 & 9,051 & 1.01 & 90.00 \\
\hline
\end{tabular}

In 2014, 4,023 properties were analyzed, while in 2015 was 3706 properties (Figure 1), in which a total of 19,805 horses were examined, obtaining a mean seropositivity for 2014 of $10.754(1.15 \%)$ and $9.501(1.01 \%)$ for 2015 . These results are similar to those found by Almeida et al. (2006) in the state of Minas Gerais (1.1\%) On the other hand, high percentages of EIA were found in the municipality of Uruará in $2002(17.71 \%)$ and in municipalities of Ilha do Marajó (46.26\%), both located in the state of Pará (FREITAS et al. 2015; HEIDMANN et al. 2002). Heidmann et al. (2002) affirm that these high occurrences are related to the significant influence of the Amazon region, which is ecologically favorable for the survival of vectors, a factor of great relevance in the transmission of this disease to horses.

The first case of EIA in the state of Rondônia was reported in 1982, in a purebred Arabian horse belonging to the experimental unit of the Brazilian
Agricultural Research Corporation (Embrapa). According to technical report $\mathrm{n}^{\circ} 5$, published in 2002, 7,283 horses were examined, of which $6.14 \%$ tested positive for EIA. From that year onwards, the Agrosilvopastoral Sanitary Defence Agency of the State of Rondônia (IDARON) initiated strict sanitary controls, by means of monitoring the transit of animals at events and border crossings as well as through actions aimed at outbreaks of the disease. By 2011, during which 16,314 animals were examined, the prevalence of EIA in the state had fallen to $1.4 \%$. The results presented in the present study, with a low incidence of positivity observed for EIA in 2014 (1.15\%) and 2015 (1.01\%), clearly confirm the importance of the actions carried out by IDARON in reducing the occurrence of this disease among horses.

The occurrence of outbreaks (Figure 5) in 2014 ranged from three to 13 per locality, while in 2015 there were between 2 to 10 per locality, with a 
significant decrease in the number of occurrences in several municipalities in the state of Rondônia. During analysis of the monthly distribution of seropositivity for EIA in the present study, it was verified that the months of October 2014 and June 2015 represented highs in the number of positive cases of $2.73 \%$ and
$2.57 \%$ respectively among the animals tested. The higher prevalence of the disease in these months may be related to rainfall indexes and, consequently, to increases in the number of tabanids and other vectors as observed by Lage et al. (2007).

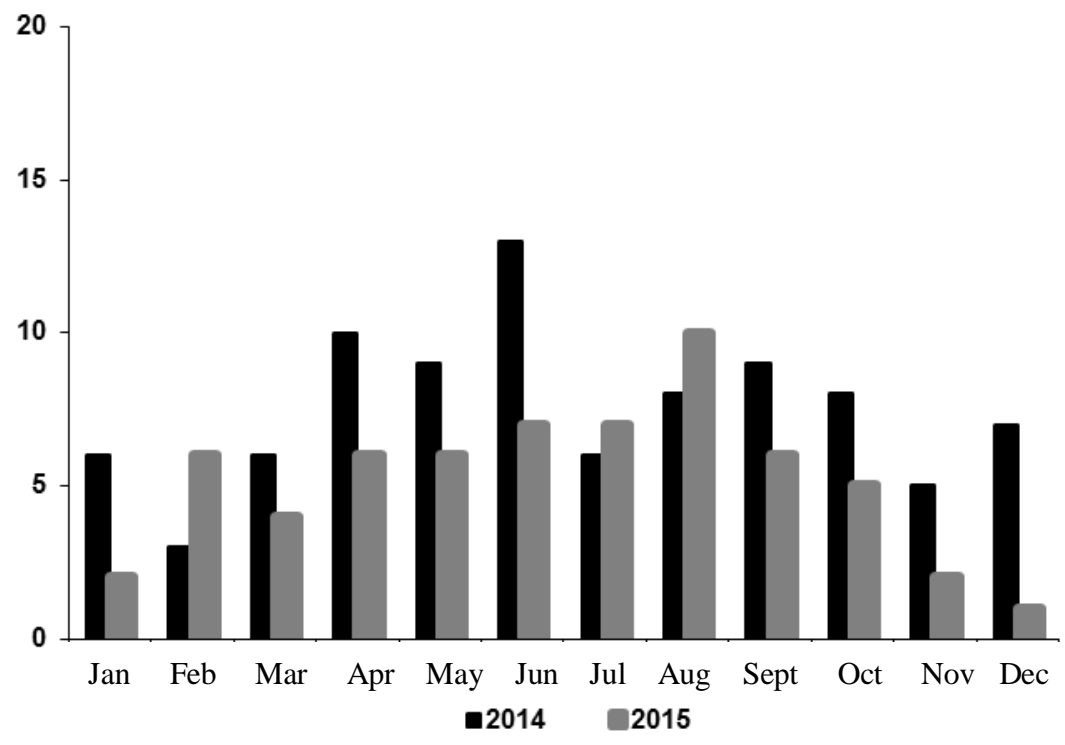

Figure 5 - Number of outbreaks distributed in the state of Rondônia, from January 2014 to December 2015.

\section{CONCLUSION}

Despite the low rate of occurrence of horses that are serologically positive for the EIA virus in the survey conducted by IDARON in the state of Rondônia, the sanitary control procedures imposed by the agency on the slaughter of sick animals, $95.97 \%$ in 2014 and $90 \%$ in 2015 , resulted in a $28.22 \%$ decrease in the number of positive animals between 2014 and 2015.

\section{REFERÊNCIAS}

ALMEIDA, V. M. A., GOLÇALVES V. S. P.; MARTINS, M. F.; HADDAD, J. P. A.; DIAS, R. A.; LEITE R. C.; REIS, J. K. P. Anemia infecciosa eqüina: prevalência em equiídeos de serviço em Minas Gerais. Arquivo Brasileiro de Medicina Veterinária e Zootecnia. v.58, n.2, p.141-148, 2006.

BORGES, M. C. M. A.; SILVA, A, L. G.; NOGUEIRA, M. F.; OLIVEIRA, C. S. A.; SEGRI, N. J.; FERREIRA, F.; WITTER, R.; AGUIAR, D. M. Prevalence and risk factors for Equine Infectious Anemia in Poconé municipality, northern Brazilian Pantanal. Research in Veterinary Science. v.95, p.7681, 2013.

COOK, R. F.; LEROUX, C.; ISSEL, C. J. Equine infectious anemia and equine infectious anemia virus in 2013: A review.Veterinary Microbiology. v.167, p.181-204, 2013.
FRANCO, M. M. J; PAES, A. C. Anemia infecciosa equina: revisão de literatura. Veterinária Zootecnia. v.18, p.197-207, 2011.

FREITAS N. F. Q. R.; OLIVEIRA C. M. C.; LEITE R. C.; REIS, J. K. P.; OLIVEIRA, F. G.; BOMJARDIM, H. A.; SALVARANI, F. M.; BARBOSA, J. D. Equine infectious anemia on Marajo Island at the mouth of the Amazon river. Pesquisa Veterinária Brasileira. v.35, p.947-950, 2015.

HEINEMANN, M. B.; CORTEZ, A.; SOUZA, M. C. C.; GOTTI, T.; FERREIRA, F.; HOMEM, V. S. F.; FERREIRA NETO, J. S.; SOARES, R. M.; SAKAMOTO, S. M.; CUNHA, M. S.; RICHTZENHAIN, L. J. Soroprevalência da anemia infecciosa equina, da arterite viral dos equinos e do aborto viral equiino no município de Uruará, PA, Brasil. Brazilian Journal of Veterinary Research and Animal Science. v.39, p.50-53, 2002.

LAGE, R. A.; QUEIROZ, J. P. A. F.; SOUSA, F. D. N.; AGRA, G. D.; IZAEL, M. A.; DIAS, R. V. C. D. Fatores de risco para a transmissão da anemia infecciosa equina, leptospirose, tétano e raiva em criatórios equestres e parques de vaquejada no município de Mossoró, RN. Acta Veterinária Brasílica. v.1, p.84-88, 2007.

NARDINI, R.; AUTORINO, G. L.; RICCI, I.; FRONTOSO, R.; ROSONE, F.; SIMULA, M.; 
SCICLUNA, M. T. Validation according to OIE criteria of a monoclonal, recombinant p26-based, serologic competitive enzyme-linked immunosorbent assay as screening method in surveillance programs for the detection of Equine infectious anemia virus antibodies. Journal of Veterinary Diagnostic Investigation. v.28, p.88-97, 2016.

RICOTTI, S.; GARCIA, M. I.; VEAUTEB, C.; BAILAT, A.; LUCCA, E.; COOK, R.F.; COOK, S. J.; SOUTULLO, A. Serologically silent, occult equine infectious anemia virus (EIAV) infections in horses. Veterinary Microbiology. v.187, p.41-49, 2016.
SILVA, I. C.; MARCHIORI FILHO, M.; SOUZA, L. M.; BELO, M. A. A.; SANDOVAL, G. A.; SCHUTZER, C. G. C.; MANRIQUE, W. G.; JACULI, A. Antihelmintic efficacy of ivermectin or mebendazol in horses. Brazilian Journal of Equine Medicine. v.62, p.22-24, 2015.

TANG, Y. D.; ZHANG, X.; NA, L.; WANG, X. F.; FU, L. H.; CHUN-HUI ZHU, C. H. Double-strandedRNA-specific adenosine deaminase 1 (ADAR1) is proposed to contribute to the adaptation of equine infectious anemia virus from horses to donkeys. Archives of Virology. v.161, p.2667-2672, 2016. 